\title{
Pollen heteromorphism in Schleichera Lour. (Sapindaceae), observed in surface soil samples from central India
}

\author{
MD. FIROZE QUAMAR*, BISWAJEET THAKUR, VEERU KANT SINGH, \\ and S.K. PANDEY \\ Birbal Sahni Institute of Palaeosciences, Lucknow-226007, India; e-mail: quamar_bot@yahoo.co.in, \\ mohdfiroze_quamar@bsip.res.in
}

Received 4 February 2021; accepted for publication 28 May 2021

\begin{abstract}
Angiosperms display striking variation of pollen morphological features within and between populations of the same species, as well as within individual plants. We describe and illustrate variation of pollen aperture number, which is called pollen heteromorphism, in Schleichera Lour. (Sapindaceae) from surface soil samples collected from central India, based on combined observations from light microscopy (LM) and confocal laser scanning microscopy (CLSM). Tri-zono-parasyncolporoidate pollen grains are, in general, known to occur in Schleichera Lour., but occasional tetra-zono-parasyncolporoidate pollen is also recorded, for the first time, from Chhattisgarh State, central India. Changes in ploidy level (diploidy/polyploidy), chromosome number, the C-value of DNA, completion of meiosis, as well as environmental factors and/or pollination ecology could be driving the occurrence of pollen heteromorphism. The present study could provide insights into the phylogeny and systematics, and has implications for pollen preservation as well.
\end{abstract}

KEYWORDS: heteromorphism, Schleichera Lour. pollen, ploidy, phylogeny and systematics, preservation, surface soil, Chhattisgarh (central India)

\section{INTRODUCTION}

Angiosperms display surprisingly frequent variability of pollen morphological characteristics such as grain size and shape, aperture number and pollen wall architecture (exine thickness and ornamentation pattern) which are likely to affect fertilization success, as different morphologies are favoured in different local competitive and ecological environments (Wodehouse, 1959; Erdtman, 1966; Dajoz et al., 1991; Pire and Dematteis, 2007). Pollen grains of angiospermous plants have been divided into two fundamental types: monoaperturate pollen or its derivatives, and triaperturate pollen or its derivatives. Triaperturate pollen is essentially restricted to dicotyledons, whereas monoaperturate (sulcate) pollen is found in

\footnotetext{
Corresponding author
}

gymnosperms, monocotyledons and some Ranalean dicots (Erdtman, 1966; Walker and Doyle, 1975; Bhowmik and Datta, 2012). Pollen may differ between individuals of a population (polymorphism) or within the same plant (heteromorphism: production of multiple types of fertile pollen grains in individual species). Amongst the various sorts of variation of pollen morphological features that occur within and between populations of the same species, as well as within individual plants, variation in the number, as well as arrangement and dispensation of apertures (opening or thinning of the exine of a pollen grain through which a pollen tube may germinate) appear to be the most common type of variation (Mignot et al., 1994; Pire and Dematteis, 2007), especially within the eudicots, such as Fabaceae (Ferguson, 
1980; Pardo, 1990), Gentianaceae (Erdtman et al., 1961; Punt and Nienhuis, 1976; Rao and Chinnappa, 1983a; Diez, 1987; Makino, 1991; Pire and Dematteis, 2007), Clusiaceae (Clarke, 1975), Krameriaceae (Pozhidaev, 2002), Solanaceae (Till-Bottraud et al., 1995; Ressayre et al., 2002) and Violaceae (Dajoz et al., 1993; Till-Bottraud et al., 1999; Nadot et al., 2000). Humphrey (2016) studied pollen heteromorphism in Thalictrum Tourn. ex. L. (Ranunculaceae), which comprises 36 species, and found that pollen aperture-number heteromorphism occurred within all Thalictrum species studied. Variation in the number of pollen apertures has also been reported in several species of Nymphaeaceae and Nelumbonaceae (Bhowmik and Datta, 2012), Capsella bursa-pastoris (L.) Medik. (Siddhanta et al., 2018), in some species of Centaurium Hill. (Gentianaceae) (Pire and Dematteis, 2007), Syzygium R. Br. ex Gaertn. (Myrtaceae) and Eucalyptus L' Hér. (Myrtaceae) (Kailas et al,. 2016), and in Schleichera oleosa (Lour.) Oken. (Sapindaceae) (Nayar, 1990).

In this communication we present the variation of pollen grain size, shape and aperture number in Schleichera Lour., a monotypic genus of the soapberry family (Sapindaceae) on the basis of combined LM and CLSM observations of material from surface soil samples collected from Timanbhauna village in the Kartala Forest Range in Korba District, Chhattisgarh State, central India. The pollen is dimorphic for shape (called pollen dimorphism) and heteromorphic for aperture number (pollen heteromorphism) in this monotypic genus containing Schleichera oleosa (Lour.) Oken. The morphological features of this monotypic genus are described and illustrated, based on LM and CLSM studies. The results have implications for the phylogeny and evolution, as well as for the taxonomy and systematics of the angiosperms, and for pollen preservation.

\section{STUDY AREA}

Timanbhauna village $\left(22^{\circ} 17^{\prime} 12.80^{\prime \prime} \mathrm{N}, 82^{\circ}\right.$ $59^{\prime} 05.22^{\prime \prime} \mathrm{E}$; $\sim 300 \mathrm{~m}$ a.s.l.) is situated about $45 \mathrm{~km}$ east of Korba Township in the Kartala Forest Range (Fig. 1) in Korba District, Chhattisgarh State, central India. The average elevation of the area is $250-350 \mathrm{~m}$ a.s.l. Moist and dry tropical deciduous forests are the main vegetation of the study area (Champion and
Seth, 1968). Tropical savannah-type climate and Mesothermal climate-Gangetic Plaintype climate (Köppen, 1936; Quamar and Kar, 2020a) are found around the area under investigation (Quamar, 2019).

\section{MATERIALS AND METHODS}

We procured 20 surface soil samples from the edge of forested areas around Timanbhauna village in the Kartala Forest Range of Korba District to study the pollen deposition pattern in the region, an aspect that has been dealt with in another communication (Quamar, 2019). While studying and scanning the samples, we observed variations in pollen size and shape and in the number of apertures in Schleichera Lour. The protocol for extraction of pollen from the studied substrate followed the standard acetolysis method (Erdtman, 1952). Chemical treatments removed humus, silica and cellulose using $10 \% \mathrm{KOH}, 40 \% \mathrm{HF}$ and an acetolysis mixture [concentrated sulphuric acid $\left(\mathrm{H}_{2} \mathrm{SO}_{4}\right)$ and acetic anhydride $\left(\mathrm{C}_{4} \mathrm{H}_{6} \mathrm{O}_{3}\right), 1: 9$ ratio]. Samples were finally prepared in $50 \%$ glycerine solution for microscopic examination. A few drops of phenol were added to avoid microbial contamination.

Temporary slides were prepared for palynological studies, carried out using an Olympus BX50 microscope (transmitted light microscope) with attached DP26 software for photography at the Quaternary Palynology Laboratory of the Birbal Sahni Institute of Palaeosciences (BSIP), Lucknow. Measurements of pollen in polar and/or equatorial views were recorded during the analysis. Shape, size/overall dimensions, symmetry, polarity, aperture (colpi and pores if visible) diameter and pollen wall architecture (exine thickness, pattern, etc.) were included for description. Pollen identification was assisted by authored/published reference materials (Quamar and Chauhan, 2011, 2012; Quamar and Bera, 2017; Quamar, 2019, 2021; Quamar and Kar, 2020b; Quamar et al., 2021). More than 300 terrestrial pollen grains (total pollen sum, TPS) were counted per sample. Terminology used for describing morphology of the studied plant pollen taxon is in accordance with Erdtman (1952), Faegri and Iversen (1964), Walker and Doyle (1975), Punt et al. (2007) and Hesse et al. (2009).

CLSM investigations were carried out at the CLSM and Raman Spectroscopy Laboratory of the BSIP, Lucknow. The same temporary slides were used for capturing images of the studied plant pollen taxon. LM shows the general structure of pollen grains, whereas CLSM reveals ultrastructural details of pollen walls in the absence of transmission electron microscopy (Shute et al., 1996; Salih et al., 1997; Feist-Burkhardt and Pross, 1999; Hochuli and Feist-Burkhardt, 2004), and provides information on the shape of pollen grains (Vitha et al., 2009). CSLM allowed us to obtain rapid, non-destructive, high-resolution images and 3D characterization of the pollen grains, distinguishing internal wall structures and ill-defined morphological features of the pollen grains that cannot be discerned by LM. CLSM has advantages over electron microscopy (Scanning Electron Microscope: SEM and Transmission 


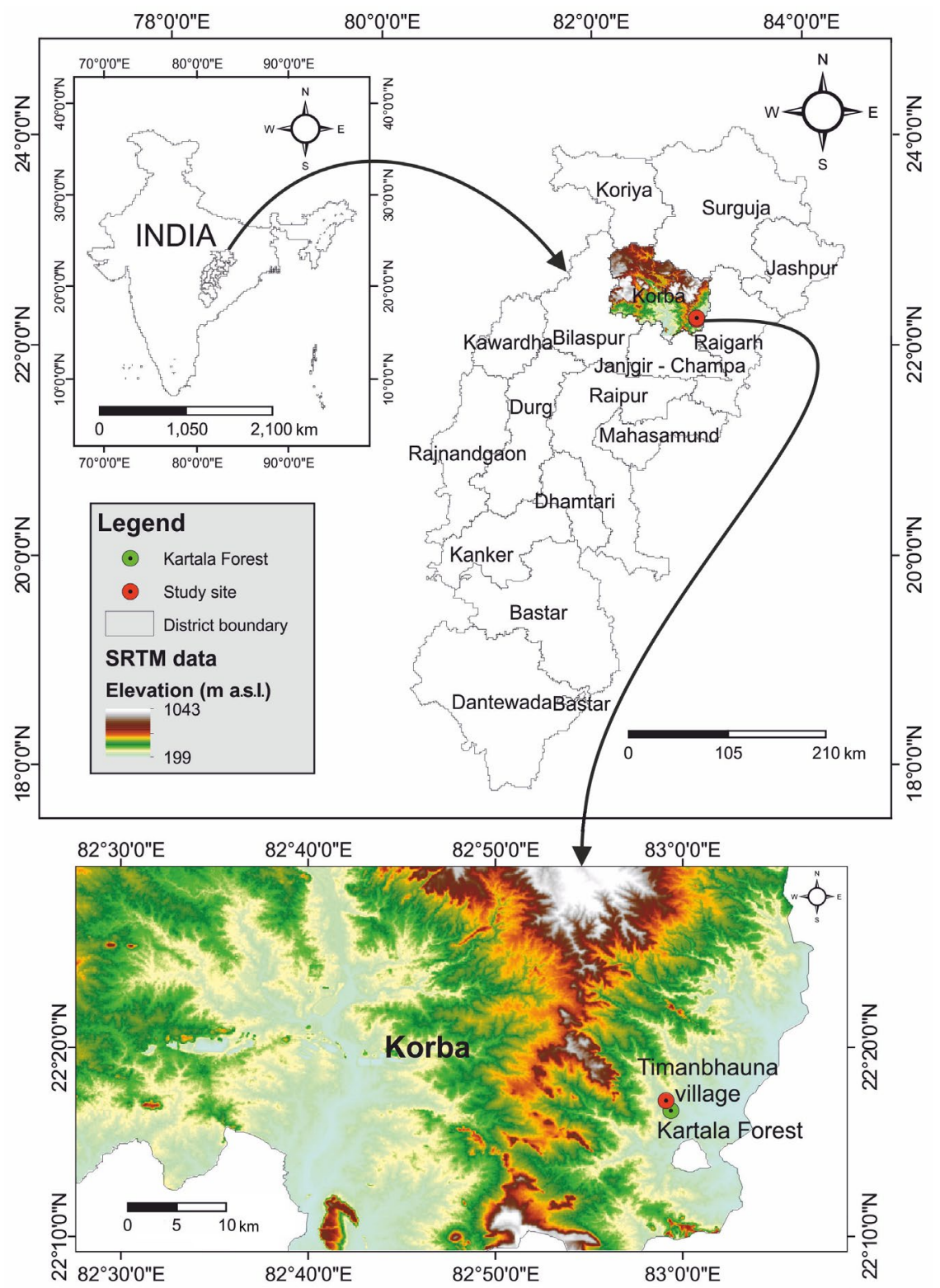

Fig. 1. Shuttle radar topographic mission (SRTM) digital elevation map (DEM) of Korba District, Chhattisgarh State, central India, showing the location of the study area in the Kartala Forest Range (red circle indicates the sampling site). Source of Figure 1: created using ArcGIS 10.3.

Elcectron Microscope: TEM) in terms of sample preparation methods and time consumption. For details of the protocol adopted for CLSM studies and the importance of the study, see Quamar et al. (2017).

\section{OVERVIEW \\ OF THE MONOTYPIC GENUS}

Schleichera Lour. is a monotypic genus, containing only one species, Schleichera oleosa (Lour.) Oken, a plant in the soapberry family, Sapindaceae. This deciduous (nearly evergreen) tree taxon (common name: Lac tree/Gum lac tree/Ceylon Oak/Sugar Apple/Kusum/Kussum) grows naturally from the foothills of the Himalayas and the Western Deccan to Sri
Lanka and China. It probably was introduced to Malaysia and naturalized in Indonesia. It occurs sporadically, seldom gregariously, in dry mixed deciduous forests, and grows in rocky, gravelly or loamy, slightly acidic, welldrained soil in central India, Bihar and southern parts of India (Mabberley, 1987; Kundu and Schmidt, 2011; www.SL.ku.dk: PROSEA, Tab. 1). It also is occasionally cultivated throughout the tropics, especially in India. It is sometimes found in swampy locations but usually grows on rather dry soil at low latitudes, and can also be found at 900-1200 m a.s.l. with rainfall requirements ranging from $750 \mathrm{~m}$ to $2800 \mathrm{~m}$ and ambient temperature of $35-47.5^{\circ} \mathrm{C}$. The tree has tremendous economic 
importance as it hosts the lac insect, the bark of the tree is used for tanning, the unripe fruit is used to make pickles, and the seeds for Macassar oil, candles, hair-dressing, soap and illumination.

\section{RESULTS AND OBSERVATIONS}

The combined LM and CLSM studies of the pollen morphology of Schleichera oleosa (Lour.) Oken. led to significantly higher taxonomic resolution. Detailed palynological descriptions of this monotypic genus are given below (Tab. 1, Pl. 1, figs 1-8).

\section{Sapindaceae}

Schleichera oleosa (Lour.) Oken.

Tab. 1, Pl. 1, Type I: figs 1-4; Type II: figs 5-8

Type I. Pollen grain tri-zono-parasyncolporoidate $^{1}$, oblate spheroidal $(25 \times 25 \mu \mathrm{m})$, bilateral (symmetry), isopolar (polarity), colpi long and broad (brevicolpi; length $6 \mu \mathrm{m}$, width $0.5 \mu \mathrm{m}$ ), apices acute; margin smooth; os indistinct, colpi (all three colpi) fused together and forming a triangular structure (apocolpium; $8 \times 6 \mu \mathrm{m}$ ), exine $0.9 \mu \mathrm{m}$ thick, sexine slightly thicker than nexine, ornamentation pattern striate.

Type I is encountered at moderate values, up to $6 \%$ of the TPS.

Type II. Pollen grain tetra-zono-parasyncolporoidate $^{1}$, oblate $(25 \times 28 \mu \mathrm{m})$, bilateral (symmetry), isopolar (polarity), colpi (brevicolpi; long and broad (length $6 \mu \mathrm{m}$, width $0.5 \mu \mathrm{m}$ ), apices acute; margin smooth; os indistinct, colpi (all four colpi) fused together, forming a quadrangular structure (apocolpium, $5 \times 10 \mu \mathrm{m}$ ), exine $0.9 \mu \mathrm{m}$ thick, sexine slightly thicker than nexine, ornamentation pattern striate.

Type II is encountered sporadically at very low values $(\sim 0.33 \%)$ of the TPS.

Mode of pollination. Entomophilous.

Habit. Tree.

1 Parasyncolporoidate condition: The condition in which the colpi of pollen grain(s) bifurcate at their ends and meet with each other, forming an intact apocolpium (the area at the pole of a zonocolpate grain delimited by the ends of colpi) at the poles. As the os is not at all clear, the term 'parasyncolporoidate' has been provided. Furthermore, the term 'zono' is used to represent the apertures [colpi (singular: colpus) or ora (singular: os) and/or both] of pollen grain(s) if arranged in an equatorial zone (Nayar, 1990)
H a bi t a t. Foothills of the Himalayas and Western Deccan. Origin (geographic): South Asia.

Information on the mode of pollination, habit, habitat and geographic distribution will aid in palaeoecological interpretations (Quamar et al., 2017).

\section{DISCUSSION}

\section{GENERAL DISCUSSION \\ OF POLLEN APERTURE HETEROMPHISM}

Variation of pollen aperture number within individual grain types, as well as pollen size and shape, can be genetically determined and heritable (Cruzan, 1990; Dajoz et al., 1993; Mignot et al., 1994; Till-Bottraud et al., 1995; Sarkissian and Harder, 2001), and aperture numbers may be determined by the distribution of microtubules during meiotic divisions of the pollen tetrad (Ressayre et al., 2002; Via do Pico and Dematteis, 2010). Environmental factors (Pire and Dematteis, 2007) and/or changes in ploidy level (Mignot et al., 1994; Dajoz et al., 1995; Nadot et al., 2000; Sousa et al., 2012; Siddhanta et al., 2018) are among the factors that may drive the morphological variation in pollen. Stainier et al. (1967) and Nadot et al. (2000) suggested that pollen aperture number is determined just after the completion of meiosis, when microspores are still grouped in tetrads. In tobacco (Nicotiana sp.), Ressayre et al. (1998) observed that the structure of the meiotic spindle is dependent on the ploidy level of the mother cell, and suggested that this structure, in turn, influences the relationships among the four microspores, leading to different pollen morphs with different aperture numbers within the same tetrad. Van Campo (1976), Chaloner (1976) and Doyle and Hotton (1991) opined that aperture number has increased over geological time.

The occurrence of different pollen morphologies, especially increase in the number of apertures, can be directly correlated with pollen tube germination. Some evolutionary mechanisms have been identified which were related to the relationship between aperture number and pollen germination (pollen grain fitness), on the one hand, and its physiology (survival/ life expectancy) on the other (Till-Bottraud et al., 1994; Nadot et al., 2000). Selection acts on increased aperture number through an increase in germinability and a decrease in 
Table 1. Schleichera oleosa (Lour.) Oken.: overview of the monotypic genus (Mabberly, 1987; Ohri et al., 2004; Kundu and Schmidt, 2011, www.SL.ku.dk; PROSEA)

\begin{tabular}{|c|c|c|}
\hline \multirow{2}{*}{ Monotypic genus } & Scientific name & Schleichera oleosa (Lour.) Oken. \\
\hline & Common name & Lac tree/Gum lac tree/Ceylon Oak/Sugar Apple/Kusum/Kussum \\
\hline \multicolumn{2}{|l|}{ Synonyms } & $\begin{array}{l}\text { Schleichera trijuga (Willd et Klein), } \\
\text { Cussambium oleosum O. Kuntze, } \\
\text { Pistacia oleosa Lour. }\end{array}$ \\
\hline \multicolumn{2}{|l|}{ Habit } & Tree \\
\hline \multicolumn{2}{|l|}{ Family } & Sapindaceae \\
\hline \multicolumn{2}{|l|}{ Phenology } & Feb.-Sept. (February-April to July-September) \\
\hline \multicolumn{2}{|l|}{ Mode of pollination } & Entomophilous \\
\hline \multicolumn{2}{|l|}{ Origin (geographic) } & South Asia \\
\hline \multicolumn{2}{|c|}{ Chromosome number $(2 \mathrm{n})^{*}$} & 32 \\
\hline \multicolumn{2}{|l|}{ Ploidy level (x) } & 2 \\
\hline \multicolumn{2}{|c|}{$\begin{array}{l}\text { Genome size 2C DNA amount/ ploidy level } \\
\text { (picograms; } \mathrm{pg}^{* * *} \text { ) }\end{array}$} & 1.17 \\
\hline \multicolumn{2}{|c|}{ 4C DNA amount \pm s.d. $(\mathrm{pg})$} & $4.66 \pm 0.30$ \\
\hline \multicolumn{2}{|c|}{ 1C DNA amount (mega-base pairs; Mbp) } & 1142 \\
\hline
\end{tabular}

* Chromosome number taken from: http://www.mobot.org; PROSEA

*** $1 \mathrm{pg}=980 \mathrm{Mbp}$ (Cavalier-Smith, 1985)

pollen survival. Pollination ecology will then determine which pollen type is the fittest in a particular environment. The size and aperture number of a pollen grain may significantly influence the fertilization success of individual grains and, thus, individual plant fitness. The growth of the pollen tube is faster and longer in a large-sized grain (Aizen and Raffaele, 1998; Tejaswini, 2002). Four-aperturate pollen (of the genus Viola) germinated faster (positive correlation), but produced shorter pollen tubes in vitro and had reduced longevity (negative correlation) as compared to 3-aperturate pollen grains (Dajoz et al., 1991). Abiotic factors may also influence pollen grain development and induce a plastic response to the local environment (Till-Bottraud et al., 1995; Lau and Stephenson, 1993). The evolutionary increase in aperture number was driven by an advantage at germination, but could be offset by a reduction in longevity. These two selective forces can sometimes balance each other to maintain several pollen morphs simultaneously (Mignot et al., 1994).

Stebbins (1971) asserted that polyploidy can cause an increase of cell size in plants that could lead to enlargement of some organs (e.g. flowers and seeds). Katisiotis and Forsberg
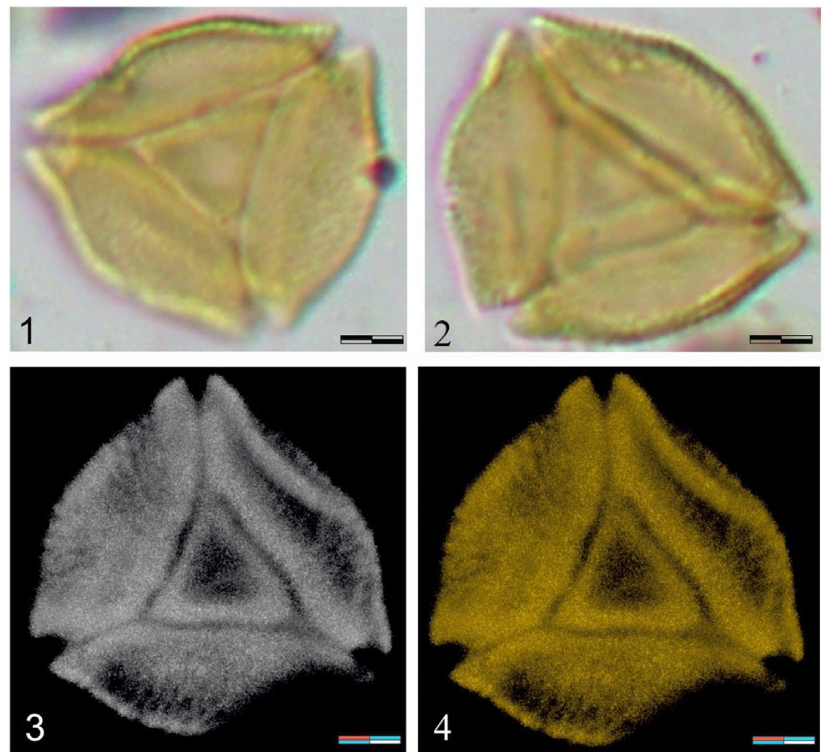
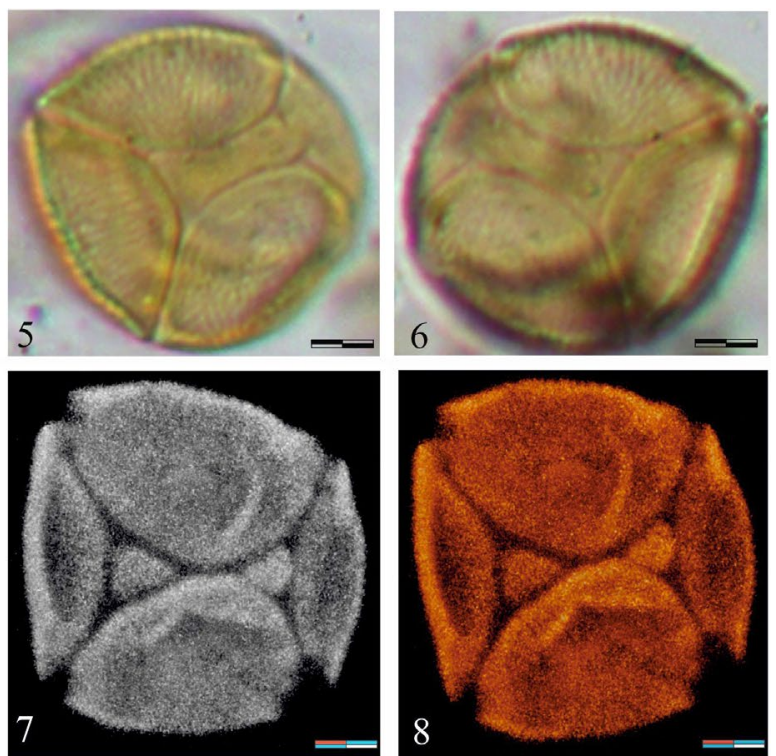

Plate 1. 1-4. Type I: Schleichera oleosa (Lour.) Oken.; 1, 2. LM micrograph; 3, 4. CLSM images, showing the tri-zono-parasyncolporoidate condition and striate ornamentation; 5-8. Type II: Schleichera oleosa (Lour.) Oken.; 5, 6. LM micrograph; 7, 8. CLSM images showing the tetra-zono-parasyncolporoidate condition and striate ornamentation. Scale bar $=10 \mu \mathrm{m}$ 
(2005) and Celenk et al. (2008) have reported this positive relationship between ploidy level and pollen size for several plant genera in natural or artificially induced polyploids. Sousa et al. (2013), however, found a positive association between the chromosome number and size of pollen grains and also between the length and width of the colpi in species of Lippia L. (Verbenaceae). Campos et al. (2011) also observed a positive correlation between chromosome number and the DNA C-value for 28 species of Lippia L. (Verbenaceae).

\section{IMPLICATIONS FOR PHYLOGENY}

Pollen grains can be categorised as primitive or advanced simply by examining the presence or absence of ornamentation on the exine and/or the number of apertures they possess. According to Nadot et al. (2000) and Yildiz et al. (2009), pollen grains whose exine surface is smooth or slightly ornamented and has fewer pores/colpi are primitive, while those with extremely ornamented exine having more pores/colpi are advanced. In the present study we observed that Schleichera oleosa (Lour.) Oken. Type II, having the tetra-zono-parasyncolporoidate condition, is advanced, whereas Schleichera oleosa (Lour.) Oken. Type I, having the tri-zono-parasyncolporoidate condition, is primitive.

The soapberry family (Sapindaceae), consisting of 138 genera and 1858 species, is eurypalynous, meaning that the plants of this family produce different pollen grains. Detailed pollen morphological studies of this family, based on LM and CLSM, as well as SEM, of this family are needed to establish the details of this. On the basis of the above suggested characteristics, the different taxa of this family and of other families might also be assessed and categorised as primitive and advanced. The suggestion that an increase in the number of pollen apertures is a derived condition (Nadot et al., 2000; Yildiz et al., 2009) and the prediction of pollen heteromorphism as an evolutionary stable strategy (ESS) (Till-Bottraud et al., 1994) point to the evolutionary and phylogenetic significance of the phenomenon of pollen heteromorphism in this monotypic genus.

\section{IMPLICATIONS FOR SYSTEMATICS}

Pollen characters were used in the classification of Orchidaceae, for the first time, by
Lindley in 1830. Erdtman (1952), Faegri and Iversen (1964) and Chanda et al. (1988) used the pollen characters for classifying taxa of various ranks. Cranwell (1952), Erdtman (1952, 1957), Wodehouse (1965) and Selling (1947) also stressed the significance of pollen morphology in plant taxonomy and systematics.

Our detailed LM- and CLSM-based illustrated pollen morphological studies of Schleichera oleosa (Lour.) Oken. (Pl. 1) may be of great help in correctly identifying and palynotaxonomically characterizing it at species level and may help differentiate it from species of Syzygium R.Br. ex Gaertn. spp. and Eucalyptus L' Hér. spp. (both belonging to the family Myrtaceae). This type of work could aid in establishing the modern pollen-vegetation relationship and also help in using fossil pollen records for reconstruction of past vegetation dynamics and the associated climate change (Quamar and Bera, 2017, 2020; Quamar and Kar, 2020a,b; Kar and Quamar, 2019, 2020; Quamar, 2021; Quamar et al., 2021, and references cited therein).

\section{IMPLICATIONS FOR POLLEN PRESERVATION}

Pollen preservation generally depends on intrinsic pollen characters, which comprise exine thickness and sporopollenin concentration, grain size and nexine ornamentation types (Havinga, 1964, 1967, 1984), as well as environmental factors, such as oxidation, soil $\mathrm{pH}$, humidity, organic matter concentration and microbial and fungal action (Havinga, 1967; Campbell and Campbell, 1994). Pollen grains with thin and smooth exine are more vulnerable and more easily damaged than are pollen grains with thick and sculptured exine (Xu et al., 2016). Plant pollen taxa with advanced morphological characters and thick exine have high preservation potential, and vice-versa. In terms of pollen preservation potential, Schleichera oleosa (Lour.) Oken. may be regarded as vulnerable to moderately vulnerable on the basis of exine thickness and ornamentation, as well as advanced pollen morphological characters. The preservation potential of different pollen grains of the various taxa of the family Sapindaceae and other families can also be determined, based on pollen wall architecture (exine thickness and ornamentation pattern) and their detailed pollen morphology. 


\section{CONCLUSIONS AND PROSPECTS}

1. Pollen heteromorphism in Schleichera oleosa (Lour.) Oken. (Sapindaceae), recorded as sporadic (Type I up to $6 \%$ and Type II $\sim 0.33 \%$ of TPS), could be due to changes in ploidy level (diploidy/polyploidy). The diploid (2n) chromosome number in this monotypic genus is 32 (haploid number of chromosome $\mathrm{n}=16$ ) and the ploidy level is 2 .

2. The role of the environment and pollination ecology cannot be ruled out, as these factors could also be driving the increased number of apertures in this monotypic genus.

3. Molecular and phylogenetic studies are required to confirm the possible causes of pollen heteromorphism in particular genera/ species.

4. The unusual and unexpected variation in the number of pollen apertures in the studied monotypic genus, often overlooked, can provide important insights into angiosperm diversity. The present study can help in testing adaptive hypotheses relating pollen grain morphology to the ecological and competitive environments, as the variation could suggest the ecological background or competition between the two existing types of pollen grains, exerting evolutionary pressure.

5. The study has implications for phylogeny and evolution, as well as for taxonomy and systematics. Also, the preservation potential of pollen grains of this monotypic genus of the soapberry family (Sapindaceae) can also be determined.

6. The study should help improve the identification of fossil pollen grains of this moist (nearly evergreen) element of tropical deciduous forests, recovered from various natural pollen trapping media/substrates (e.g. surface soil samples, profile/core sediment samples). This should be of help in establishing modern pollen-vegetation relationships, as well as in reconstructing past vegetation dynamics and the associated climate change through analysis of pollen from tropical deciduous forests in India and from similar tropical and subtropical regions of the world.

7. Detailed morphological studies of material from mature floral buds and immature flowers of extant plants and/or flower buds of herbarium specimens from the study area are needed to corroborate the phenomenon of pollen aperture heteromorphism.

\section{ACKNOWLEDGEMENTS}

We thank Dr. (Mrs.) Vandana Prasad, Director of the Birbal Sahni Institute of Palaeosciences (BSIP), Lucknow, India, for providing the infrastructure facilities needed to complete the research work and also for permission to publish. We also thank two anonymous reviewers for their critical comments which greatly helped us to improve the earlier version of the manuscript, and Dr. Maria Barbacka, Editor, Acta Palaeobotanica, for encouragement.

\section{REFERENCES}

Aizen, M., Raffaele, E., 1998. Flowering-shoot defoliation affectspollen grain size and postpollination pollen performance in Alstroemeria aurea. Ecology 79, 2133-2142. https://doi.org/10.2307/176716

Bhowmik, S., Datta, B.K., 2012. Pollen dimorphism of several members of Nymphaeaceae and Nelumbonaceae: an index of geographical and ecological variation. Notulae Scientia Biologicae 4(3), 38-44. https://doi.org/10.15835/nsb437689

Campbell, I.D., Campbell, C., 1994. Pollen preservation: experimental wet-dry cycles in saline and desalinated sediments. Palynology 18, 5-10. https://doi.org/10.1080/01916122.1994.9989434

Campos, J.M.S., Sousa, S.M., Silva, P.S., Pinheiro, L.C., Sampaio, F., Viccini, L.F., 2011. Chromosome numbers and DNA C values in the genus Lippia (Verbenaceae). Plant Systematics and Evolution 291, 133-140. https://doi.org/10.1007/s00606-010-0370-6

Cavalier-Smith, T., 1985. The Evolution of Genome Size. Chichester: John Wiley and Sons.

Celenk, S., Tarimcilar, G., Bicakci, A., Kayank, G., Malyer, H., 2008. A palynological study of the genus Mentha L. (Lamiaceae). Botanical Journal of the Linnean Society 157, 141-154. https://doi. org/10.1111/j.1095-8339.2008.00789.x

Chaloner, W.G., 1976. The evolution of adaptative features in fossil exines. In: Ferguson, I.K, Muller, J. (eds), The evolutionary signfficance of the exine. Linnean Society Symposium, Series no 1, 1-14.

Champion, H.G., Seth, S.K., 1968. A Revised Survey of the Forest types of India. Manager of Publications, New Delhi, India.

Chanda, S., Nilson, S., Blackmore, S., 1988. Phylogenetic trends in the Alismatales with reference to pollen grains. Grana 27, 257-272. https://doi. org/10.1080/00173138809429948

Clarke, G.C.S., 1975. Irregular pollen grains in some Hypericum species. Grana 15, 117-125. https://doi. org/10.1080/00173134.1975.11864626

Cranwell, L.M., 1952. New Zealand pollen studies - the monocotyledons. Bulletin of the Auckland Institute and Museum 3, 1-91.

Cruzan, M.B., 1990. Variation in pollen size, fertilization ability, and postfertilization siring ability in 
Erythronium grandiflorum. Evolution 44, 843-856. https://doi.org/10.2307/2409550

Dajoz, I., Till-Bottraud, I., Gouyon, P.H., 1991. Evolution or pollen morphology. Science 253, 66-68. https://doi.org/10.1126/science.253.5015.66

Dajoz, I., Till-Bottraud, I., Gouyon, P.H., 1993. Pollen aperture polymorphism and gametophyte performance in Viola diversifolia. Evolution 47, 10801093. https://doi.org/10.2307/2409976

Dajoz, I., Mignot, A., Hoss, C., Till-Bottraud, I., 1995. Pollen aperture heteromorphism is not due to unreduced gametophytes. American Journal of Botany 82(1), 104-111. https://doi.org/10.1002/j.1537-2197.1995. tb15654.x

Díez, M.J., 1987. Gentianaceae. In: Valdés, B., Díez, M.J., Fernández, I. (eds) Atlas Polínico de Andalucía Occidental. Sevilla: Grafitres-Utrera. pp. 246-248.

Doyle, J.A., Holton, C.L., 1991. Diversification of early angiosperm pollen in a cladistic context. In: Blackmore, S., Barnes, S.H. (eds.), Pollen and spores, patterns of diversification. Systematics Association Special 44, Clarendon Press, Oxford. pp. 169-195.

Erdtman, G., 1952. Pollen morphology and plant taxonomy of Angiosperms. Waltham, Mass., U.S.A.

Erdtman, G., 1957. Pollen morphology and plant taxonomy. Gymnospermae, Pteridophyta, Bryophyta. Stockholm and New York. https://doi.org/10.5962/ bhl.title.5683

Erdtman, G., 1966. Pollen morphology and plant taxonomy. Hafner Publishing Company, New York.

Erdtman, G., Berglund, B., Praglowski, J., 1961. An introduction to Scandinavian pollen flora. Grana 2, 3-92. https://doi.org/10.1080/00173136109428945

Faegri, K., Iversen, J., 1964. Text book of pollen analysis. 2nd Ed. Munksgaaard. Copenhagen.

Feist-Burkhardt, S., Pross, J., 1999. Morphological analysis and description of Middle Jurassic dinoflagellate cyst marker species using confocal laser scanning microscopy, digital optical microscopy, and conventional light microscopy. Bulletin - Centres de Recherches Exploration-Production ElfAquitaine 22, 103-145.

Ferguson, I.K., 1980. The pollen morphology of Ceratonia (Leguminosae: Caesalpinoideae). Kew Bulletin 35, 273-277. https://doi.org/10.2307/4114571

Hesse, M., Halbritter, H., Zetter, R., Weber, M., Buchner, R., Frosch-Radivo, A., Ulrich, S., 2009. Pollen Terminology: An illustrated Handbook. Springer. Vienna.

Havinga, A.J., 1964. Investigation into the differential corrosion susceptibility of pollen and spores. Pollen Spores 6, 621-635.

Havinga, A.J., 1967. Palynology and pollen preservation. Review of Palaeobotany and Palynology 2, 81-98. https://doi.org/10.1016/0034-6667(67)90138-8

Havinga, A.J., 1984. A 20-year experimental investigation into the differential corrosion susceptibility of pollen and spores in various soil types. Pollen Spores 26, 541-558.
Hochuli, P., Feist-Burkhardt, S., 2004. A boreal early cradle of Angiosperms? Angiospermlike pollen from the Middle Triassic of the Barents Sea (Norway). Journal of Micropalaeontology 23, 97-104. https:// doi.org/10.1144/jm.23.2.97

Humphrey, R., 2016. Pollen heteromorphism is pervasive in Thallictrum (Ranunculaceae). Plant Systematics and Evolution 302, 1171-1177. https://doi. org/10.1007/s00606-016-1312-8

Kailas, J.G., Ramakrishna, H., Seetharam, D.S., 2016. Diversity in syncolpate pollen of arborescent taxa in Karimnagar District, Telangana State, India. Research Journal of Pharmaceutical, Biological and Chemical Sciences 7(3), 771-776.

Kar, R., Quamar, M.F., 2019. Pollen-based Quaternary palaeoclimatic studies in India: an overview of recent advances. Palynology 43(1), 76-93. https:// doi.org/10.1080/01916122.2017.1410502

Kar, R., Quamar, M.F., 2020. Late Pleistocene-Holocene vegetation and climate change from the Western and Eastern Himalaya (India): palynological perspective. Current Science 119(2), 195-218.

Katisiotis, A., Forsberg, R.A., 2005. Pollen grain size in four ploidy levels of genus Avena. Euphytica 83, 103-108. https://doi.org/10.1007/bf01678036

Köppen, W., 1936. Das geographische System der Klimate. In: Köppen, W., Geiger, R. (eds) Handbuch der Klimatologie. Gebrüder Borntraeger, Berlin, pp. 1-44.

Kundu, M., Schmidt, L.H., (ed.). 2011. Schleichera oleosa (Lour.) Oken. Seed leaflet 153.

Lau, T., Stephenson, A.G., 1993. Effects of soil nitrogen on pollen production, pollen grain size, and pollen performance in Cucurbita pepo (Cucurbitaceae). American Journal of Botany 80, 763-768. https://doi.org/10.1002/j.1537-2197.1993.tb15292.x

Lindley, J., 1830. The genera and species of orchidaceous plants. Ridgways, London.

Mabberley, D.J., 1987. The Plant Book. Cambridge: Cambridge University Press.

Makino, H., 1991. Flora polínica da Reserva do Parque Estadual das Fontes do Ipiranga (São Paulo, Brasil). Hoehnea 18, 43-48.

Mignot, A., Hoss, C., Dajoz, I., Leuret, C., Jean-Pierre H., Jean-Michel D., Heberle Bors, E., Till-Bottraud, I. 1994. Pollen aperture polymorphism in the Angiosperms: importance, possible causes and consequences. Acta Botanica Gallica 141(2), 109-122. https://doi.org/10.1080/12538078.1994.10515144

Nadot, S., Ballard, Jr. H.E., Creach, J.B., Dajoz, I., 2000. The evolution of pollen heteromorphism in Viola: a phylogenetic approach. Plant Systematics and Evolution 223, 155-171. https://doi. org/10.1007/bf00985276

Nayar, T.S., 1990. Pollen Flora of Maharashtra State, India. Today and Tomorrow's Printers and Publishers, New Delhi.

Ohri, D., Bhargava, A., Chatterjee, A., 2004. Nuclear DNA amounts in 112 species of tropical 
hardwoods-New estimates. Plant Biology 6, 555561. https://doi.org/10.1055/s-2004-821235

Pardo, C., 1990. Tipos harmomègatas en Gleditschia triacanthos (Papilionaceae, Caesalpinoideae). Polen, Esporas Aplicac. 1, 211-216.

Pire, S.M., Dematteis, M., 2007. Pollen aperture heteromorphism in Centaurium pulchellum (Gentianaceae). Grana 46(1), 1-12. https://doi. org/10.1080/00173130601101245

Pozhidaev, A.E., 2002. Hypothetical way of pollen aperture patterning. 3. A family-based study of Krameriaceae. Review of Palaeobotany and Palynology 127, 1-23. https://doi.org/10.1016/s00346667(02)00251-8

PROSEA (Plant Resources of South-East Asia). http:// uses.planet-project.org/in/Schleichera oleosa (PROSEA)

Punt, W., Nienhuis, W., 1976. The Northwest European Pollen Flora. 6. Gentianaceae. Review of Palaeobotany and Palynology 21, 89-123. https://doi. org/10.1016/0034-6667(76)90018-x

Punt, W., Hoen, P.P., Blackmore, S., Nilsson, S., Le Thomas, A., 2007. Glossary of pollen and spore terminology. Review of Palaeobotany and Palynology 143(1-2), 1-81. https://doi.org/10.1016/j.revpalbo.2006.06.008

Quamar, M.F., 2019. Palynological study of surface soil samples from the Kartala Forest Range of the Korba District, Chhattisgarh, central India: Modern pollen-rain/vegetation relationships. Geophytology 49(1\&2), 37-48.

Quamar, M.F., 2021. Monsoonal climatic reconstruction from central India during the last ca. 3600 cal yr: signatures of global climatic events, based on lacustrine sediment pollen records. Palynology (in press). https://doi.org/10.1080/01916122.2021.1930605

Quamar, M.F., Bera, S.K., 2017. Pollen records related to vegetation and climate change from northern Chhattisgarh, central India during the late Quaternary. Palynology 41(1), 17-23. https://doi.org/10. 1080/01916122.2015.1077172

Quamar, M.F., Bera, S.K., 2020. Pollen records of vegetation dynamics, climate change and ISM variability since the LGM from Chhattisgarh State, central India. Review of Palaeobotany and Palynology 278, 104237. https://doi.org/10.1016/j. revpalbo.2020.104237

Quamar, M.F., Chauhan, M.S., 2011. Late Holocene vegetation, climate change and human impact in southwestern Madhya Pradesh, India. The Palaeobotanist 60(2), 281-289.

Quamar, M.F., Chauhan, M.S., 2012. Late Quaternary vegetation, climate as well as lake-level changes and human occupation from Nitaya area in Hoshangabad District, southwestern Madhya Pradesh (India), based on pollen evidence. Quaternary International 263, 104-113. https://doi. org/10.1016/j.quaint.2012.01.001

Quamar, M.F., Kar, R., 2020a. Modern pollen dispersal studies in India: a detailed synthesis and review. Palynology 44(2), 217-236. https://doi.org/ 10.1080/01916122.2018.1557274

Quamar, M.F., Kar, R., 2020b. Prolonged warming over the last ca. 11,700 years from the central Indian Core Monsoon Zone: Pollen evidence and a synoptic overview. Review of Palaeobotany and Palynology 276, 104159. https://doi.org/10.1016/j. revpalbo.2020.104159

Quamar, M.F., Ali, S.N., Morthekai, P., Singh, V.K., 2017. Confocal (CLSM) and light (LM) photomicrographs of different plant pollen taxa from Lucknow, India: Implications of pollen morphology for systematics, phylogeny and preservation. Review of Palaeobotany and Palynology 247, 105-119. https://doi.org/10.1016/j.revpalbo.2017.09.005

Quamar, M.F., Kar, R., Thakur, B., 2021. Vegetation response to the Indian Summer Monsoon (ISM) variability during the Late Holocene from the central Indian core monsoon zone. The Holocene 31(7), 1197-1211.

Rao, K.S., Chinnappa, C.C., 1983a. Pericolporate pollen in Gentianaceae. Canadian Journal of Botany 61, 174-178. https://doi.org/10.1139/b83-018

Ressayre, A., Godelle, B., Mignot, A., Gouyon, P.H., 1998. A morphogenetic model accounting for pollen aperture pattern in flowering plants. Journal of Theoretical Biology 193, 321-334. https://doi. org/10.1006/jtbi.1998.0704

Ressayre, A., Raquin, C., Mignot, A., Godelle, B. Gouyon, P.H., 2002. Correlated variation in microtubule distribution, callose deposition during male post-meiotic cytokinesis, and pollen aperture number across Nicotiana species (Solanaceae). American Journal of Botany 89, 393-400. https://doi. org/10.3732/ajb.89.3.393

Salih, A., Jones, A.S., Bass, D., Cox, G., 1997. Confocal imaging of exine as a tool for grass pollen analysis. Grana 36, 215-224. https://doi. org/10.1080/00173139709362610

Sarkissian, T.S., Harder, L.D., 2001. Direct and indirect responses to selection on pollen size in Brassica rapa L. Journal of Evolutionary Biology 14, 456-468. https://doi.org/10.1046/j.1420-9101.2001.00285.x

Selling, O.H., 1947. Studies in Hawaiian pollen statistics, Part I and II. Bishop Museum Publ. Honolulu, Hawaii.

Shute, C., Hemsley, A.R., Strother, P., 1996. Reassessment of dyads contained in a Late Silurian Rhynophytoid sporangium. Special Papers in Palaeontology $55,137-145$.

Siddhanta, S., Bera, S., Maity, D., 2018. A note on a new pollen aperture in Capsella bursa-pastoris (L.) Medik. from Sikkim Himalaya. Palynology 42(4), 571-573. https://doi.org/10.1080/01916122.2018.1463572

Sousa, A.M., Pierre, P.M.O., Torres, G.A., Davide, L.C., Vaccini, L.F., 2013. Relationship between pollen morphology and chromosome numbers in Brazilian species of Lippia L. (Verbenaceae). Anais da Academia Brasileira de Ciências (Annals of the 
Brazilian Academy of Sciences) 85(1), 147-157. https://doi.org/10.1590/s0001-37652013005000010

Stainier, F., Huard, D., Bronckers, F., 1967. Technique de coloration spdcifique de l'exine des microspores jeunes encore groups en tetrades. Pollen et Spores 9, 367-370.

Stebbins, G.L., 1971. Chromosomal evolution in higher plants. London: Edward Arnold, 216 p.

Tejaswini, 2002. Variability of pollen grain features: a plant strategyto maximize reproductive fitness in two species of Dianthus? Sexual Plant Reproduction 14, 347-353. https://doi.org/10.1007/s00497002-0130-z

Till-Bottraud, I., Venable, L., Dajoz, I., Gouyon, P.H., 1994. Selection on pollen morphology: a game theory model. American Naturalis 144, 395411. https://doi.org/10.1086/285683

Till-Bottraud, I., Mignot, A., De Paepe, R., Dajoz, I., 1995. Pollen heteromorphism in Nicotiana tabacum (Solanaceae). American Journal of Botany 82, 1040-1048. https://doi.org/10.2307/2446234

Till-Bottraud, I., Vincent, M., Dajoz, I., Mignot, A., 1999. Pollen aperture hetero-morphism. Variation in pollen-type proportions along altitudinal transects in Viola calcarata. Comptes rendus de l'Académie des Sciences Paris, Sciences de la vie 322, 579-589. https://doi.org/10.1016/s0764-4469(00)88528-5

Van Campo, M., 1976. Patterns of pollen morphological variation within taxa. In: Ferguson, I.K., Muller, J. (eds), The evolutionary significance of the exine. Academic Press, Inc., New-York, 163-183.
Via do Pico, G.M., Dematteis, M., 2010. Meiotic behavior and pollen morphology variation in Centaurium pulchellum (Gentianaceae). Plant Systematic and Evolution 290, 99-108. https://doi.org/10.1007/ s00606-010-0352-8

Vitha, S., Bryant, V.M., Zwa, A., Holzenburgh, A., 2009. Confocal imaging of pollen. Microscopy and Microanalysis 15, 622-623. https://doi.org/10.1017/ s1431927609094367

Walker, J.W., Doyle, J.A., 1975. The bases of Angiosperm Phylogeny: palynology. Annals of the Missouri Botanical Garden 62, 664-723. https://doi. org/10.2307/2395271

Wodehouse, R.P., 1959. Pollen grains, their structure, identification, and significance in science and medicine. Hafner Pub. Co, New York.

Wodehouse, R.P., 1965. Pollen grains. their structure, identification and significance. Hafner Publ. Co, New York.

Xu, Q., Zhang, S., Gaillard, M.J., Li, M., Cao, X., Tian, F., Li, F., 2016. Studies of modern pollen assemblages for pollen dispersal-deposition-preservation process understanding and for pollen-based reconstructions of past vegetation, climate, and human impact: A review based on case studies in China. Quaternary Science Reviews 149, 151-166. https://doi.org/10.1016/j.quascirev.2016.07.01

Yildiz, K., Gucel, S., Dadandi, M.Y., 2009. A palynological investigation of endemic taxa from Northern Cyperus. Pakistan Journal of Botany 41(3), 991-1007. 